\title{
REALISMO POLÍTICO E CONFLITOS
}

\author{
Carlos Nunes Guimarães ${ }^{1}$ \\ Universidade Estadual da Paraíba (UEPB/ CCEA).
}

\begin{abstract}
RESUMO:
O artigo apresenta uma análise sobre o realismo político e os conflitos, a partir do pensamento do secretário florentino Nicolau Maquiavel. Para o autor de $O$ Príncipe, o realismo é um guia para a ação política e entre os principais elementos do realismo, há a afirmação de que a realidade política é composta de conflitos. Maquiavel compreende o conflito como uma condição inerente a própria política. O conflito é fundamental para o equilíbrio das relações na vida política. O tratamento sobre aos conflitos proposto pelo secretário florentino se coaduna com um ambiente democrático. O modelo republicano de Maquiavel não exclui nenhum segmento social. A república pensada por Maquiavel tem a marca da tolerância com as forças contrárias.
\end{abstract}

PALAVRAS-CHAVES: Realismo Político; Conflitos; Maquiavel; República.

\section{THE POLITICAL REALISM AND CONFLICTS}

\begin{abstract}
:
The article presents an analysis of the political realism and conflicts, from the thought Secretary of the Florentine Niccolo Machiavelli . For the author of The Prince, realism is a guide to political action and between the main elements of realism, there is the claim that political reality is made up of conflicts. Machiavelli understands the conflict as a condition inherent in the policy itself. The conflict is crucial to the balance of relations in political life. Treatment of the conflict proposed by the Florentine clerk consistent with a democratic environment . The republican model of Machiavelli does not exclude any social segment. The republic conceived by Machiavelli has the mark of tolerance for opposing forces .
\end{abstract}

KEYWORDS: Political Realism; Conflicts; Machiavelli; Republic.

\footnotetext{
1 Doutor em Filosofia. Professor da Universidade Estadual da Paraíba (UEPB/ CCEA), Paraíba - Brasil. E-mail: carlosguimaraespb@ hotmail.com
} 


\section{0 realismo político}

As raízes do realismo político são reconhecidas desde a antiguidade clássica, em Tucidides, no seu relato da guerra de Peloponeso. Porém, é a partir de Maquiavel que o realismo ganha maior difusão e complexidade. Maquiavel, no Capítulo XV de sua obra mais famosa, $O$ Príncipe, faz uma severa crítica àqueles que "conceberam repúblicas e principados jamais vistos e que nunca existiram na realidade". O florentino diz que o caminho para realização da política, ou a construção de uma nova realidade, deve se apoiar nos estudos da realidade factual, com os vários 'rostos' com que ela se apresenta. Por isto, de acordo com

Escorel (1981) este diplomata da republica florentina se apresenta no limiar da época moderna, como o mestre do realismo político. O seu pensamento não apenas é uma oposição a tradição Escolástica, já tão afrontada pelo Humanismo Cívico, como também, seu realismo causa efeito sobre as utopias do Renascimento e se confronta com idealizações naturais na história dos homens de que a política pode se realizar sobre a concórdia permanente e a possibilidade de o homem construir um paraíso aqui na terra.

Apesar de suas origens na Antiguidade, na Idade Média não há destaque para escritores que abordam o tema. É justamente com Maquiavel, no histórico período de transição para a Idade Moderna, que o realismo aparece teorizado no mundo da política, sendo depois dele, passagem obrigatória para autores como Thomas Hobbes, Baruc Spinoza, Hegel e outros. O realismo ganha uma maior dimensão na contemporaneidade nos estudos das relações internacionais, transformando-se em uma escola ${ }^{2}$. A

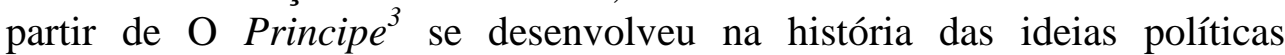
incorporando outros elementos e é indispensável para as análises das relações políticas na atualidade, sobretudo no campo das relações internacionais.

'A verdade efetiva das coisas' a que Maquiavel se refere, trata de acontecimentos reais da condição humana, num mundo de lutas e contradições, palco exclusivo de ações dos homens, um ambiente para o homem de virtù dominar e transformar seu destino. $\mathrm{O}$ secretário da república florentina procura um caminho diferente daquele trilhado por filósofos que buscavam a cidade ideal. Este pensamento ideal não tem

\footnotetext{
${ }^{2}$ No século XX destacam-se autores como Friedrich Meinecke, Max Weber, Carl Schmitt, Hans Morgenthau, Edward Carr. A forte influencia dos alemães sobre o tema o fez também ficar conhecido como Realpolitik.

${ }^{3}$ Utilizamos como fonte de referência a edição: Niccolò Machiavelli: Tutte le Opere, storiche, politiche e letterarie. A Cura di Alessandro Capata. Edizioni Integrali. Roma: Newton \& Compton editori, 2011. No corpo do texto esta obra será citada traduzida para língua portuguesa. Toda tradução é nossa.
} 
condições de dar conta das necessidades da realidade. Maquiavel afasta-se das clássicas formulações de Platão e mesmo de Aristóteles, de uma cidade ideal fundada sobre a razão, e também se distancia dos medievais que incorporaram ao pensamento dos filósofos a providência divina. A política, o Estado, os governos, são construções absolutamente humanas, independentes de quaisquer considerações metafísicas. O autor afirma, em O Príncipe:

\begin{abstract}
Muitos já escreveram sobre o assunto, temo que estas palavras possam parecer presunçosas, por discreparem, especialmente neste ponto, das opiniões de outras pessoas. Mas como minha intenção é escrever o que tenha utilidade para quem estiver interessado, pareceu-se mais apropriado abordar a verdade efetiva das coisas, e não a imaginação sobre elas (MAQUIAVEL, 1995, p. 164).
\end{abstract}

Maquiavel não esboça uma análise que simplifique o mundo da política, como os utópicos, ou mesmo uma forma de realismo que confirma nas análises a realidade a partir de formas estanques e descreve a realidade amoldando-se a esta. Além de um método para a análise da realidade política, propõe uma ação interventora para mudança desta realidade. Assim, o secretário inaugurou uma filosofia da ação política, uma práxis, como observa o teórico italiano Antonio Gramsci. Maquiavel entende que há um alto grau de complexidade na vida política e no comportamento dos homens que exige avaliação rigorosa e considere todos os fenômenos que se apresentam. Isto justifica suas análises a partir da relação dialética entre os elementos que compõem o universo político. Em suas obras aparece a tensão entre os pares virtù e fortuna; amado e temido; leis e armas; ser e parecer; liberal e avaro; coerção e persuasão; força e astúcia; etc. Há sempre uma tensão entre estas opções.

O realismo de Maquiavel considera que na política não há uma resposta pronta, definitiva e adequada que possa dar conta de todas as situações em diferentes momentos. Como não há universais, cada momento é um momento particular, cada momento exige resposta adequada a partir das experiências modernas e o acúmulo das lições do passado, por isto é um conhecimento empírico. Neste pensamento destaca-se a atenção sobre o conhecimento do homem e suas relações. É decisivo para o realismo, tentar captar o que é o homem, ou no dizer de Maquiavel, "a natureza humana", quais são seus desejos, seus anseios, suas mágoas, suas expectativas sobre si e os outros, seus limites e horizontes, sua vontade de poder.

$\mathrm{O}$ realismo se funda sobre uma antropologia negativa, um olhar pessimista sobre a condição humana. $O$ homem não se comporta completamente pela razão e é dirigido por paixões que se sobrepõem ao mundo racional. Esta condição humana o coloca diante de dramas de difícil solução que estão sempre a se revelar num mundo de insegurança, inveja, 
ódios, ambição, vontade de poder. Entretanto, mesmo reconhecendo que há uma dimensão da esfera humana não guiada pela razão, o realismo busca explicar racionalmente a realidade, desta forma, o realismo reconhece que devem ser considerados os limites da razão sobre o agir humano e, por consequência, da construção política.

Para Portinaro (2007), o realismo do lado descritivo é um paradigma epistemológico que traz a concepção de luta pelo poder, uma luta sem limites e uma concepção de Estado como fenômeno de pura força, como meio de imposição da ordem.

Contudo, o moralismo que tentou subordinar a política até os tempos de Maquiavel, negou-se a admitir que o universo político é composto de astúcia, força, violência, falsidade, dissimulação. Aquele moralismo não quis reconhecer que a política não dispensa a manobra, jogo de aparências, segredos - arcana imperii. (PORTINARI, 2007, p. 20). Por que? Porque é realizada por homens. O realismo político é o reconhecimento desta condição, ou seja, um meio de realizar análises da política, considerando e não negando esta condição. Foi pela ausência desta perspectiva que Platão e outros idealistas construíram 'cidades ideais' e falharam, não pelo desejo de construírem um 'mundo' novo, mas porque:

Embora fossem influenciados pelas instituições nas quais viviam, não se preocuparam em analisar a natureza dessas instituições e as causas subjacentes dos males que deploravam (...) elaboraram soluções altamente imaginativas, produto não da análise, mas de suas aspirações mais profundas (...) nas doutrinas políticas sempre predominam projetos teóricos e soluções utópicas, mais influenciadas pelo fim almejado do que pelo conhecimento dos fatos reais. (ESCOREL, 2001, p. 21 22).

A propósito da visão negativa sobre a natureza humana registrada por Maquiavel, depois amplificada por Thomas Hobbes justificando a fundação do Estado e que dá suporte para as análises realistas, o secretário não afirma que o homem seja portador de uma malignidade completa e insuperável. Se o homem não é completamente um ser racional, que busca sempre a harmonia na convivência com o outro, por outro lado, não é de uma malignidade incorrigível. Maquiavel sabe das contradições que compõem a 'natureza humana' e embora parta de uma antropologia pessimista, reconhece que os homens não são completamente bons ou completamente maus: "os homens não sabem guardar nenhuma dignidade no crime, nem ser perfeitamente bons (...) ou como já disse, os homens não sabem ser nem de uma virtude absoluta, nem inteiramente criminosos". (MAQUIAVEL, 2011, p. 97). Todavia, o secretário reconhece esta realidade que compõe a 'natureza humana' ou seja, estas antíteses, maldade-bondade; coragem-covardia; generosidade-mesquinhez, etc., todas porém, em potência, sujeitas às circunstancias; às condições reais para seu afloramento 
O olhar negativo sobre os homens alia-se ao rigoroso estudo do passado, como afirma Portinaro:

O realismo se alimenta do estudo do passado, da consideração do presente e da conjuntura racional ajustada a esses conhecimentos, do futuro. A autoridade da história é a experiência do presente devem ser reciprocamente ponderadas para chegar a previsões razoáveis. A experiência sem a história resulta, com efeito, cega e enquanto que a história sem a experiência pode resultar enganosa. (PORTINARI, 2007, p. 32).

As lições do passado são decisivas para o presente. Não por outro motivo, como destaca Portinaro, o realismo surge a partir da produção historiográfica na Grécia, com Tucídides. Em Maquiavel, são raros os momentos de sua obra em que não são citados exemplos históricos e ele mesmo se faz historiador. Há uma ligação intrínseca entre política e história que compõe o arcabouço teórico do secretário florentino. Anarovich (2007), lembra que $O$ Príncipe, como sabemos, não é uma obra de comentários a outra obra histórica, como os Discursos, todavia, Maquiavel faz referência a história em todo o texto, exceto apenas um único capítulo, o XV.(ANAROVICH, 2007, p. 25).

Com efeito, o realismo de Maquiavel, que pretende captar a realidade tal qual se apresenta, volta o olhar para o passado, para as experiências que podem ajudar a permitir vislumbrar as consequências das ações, porque "na verdade os homens perseguem quase sempre os caminhos já percorridos, agindo de forma imitativa (...) a pessoa prudente escolherá sempre o caminho trilhado pelos grandes homens" (MAQUIAVEL, 1995. p. 99.) A experiência do passado pretende evitar os erros no presente. O florentino quer aprender com aqueles momentos e colocar alguma luz para entender as circunstâncias dadas naquele tempo histórico da Itália.

Mas, voltar a atenção para o passado, não em busca de formulações filosóficas ou teológicas pretéritas, mas interessado em saber o que os homens fizeram; como enfrentaram seus desafios; quais foram as respostas aos difíceis momentos que se apresentavam; quais foram seus resultados; o que explica o fracasso ou sucesso de suas ações. Por isto, para Maquiavel, é indispensável uma arguta observação da realidade presente e analisá-la tendo em conta as lições passadas. Entretanto, não se exclui desta análise o olhar para o futuro, afinal Maquiavel não pensa a política no vazio, desprovido de desejo de realização, todavia, sem pensar que dele possa brotar espontaneamente uma nova ordem, mas este olhar deve ter correspondência com o passado visto em termos de causalidade.

$\mathrm{O}$ autor de $O$ Príncipe procura compreender aquele passado e o que ele pode ter de orientação para as coisas presentes. Aqui, encontra-se justamente a capacidade do homem de virtù saber adequar as lições do passado com as circunstâncias presentes, não transportando aquelas 
experiências mecanicamente, mas adequando-as a sua realidade. Os exemplos são vários nos textos maquiavelianos.

Nos Discursos, III, 09, Capítulo intitulado Como convém variar com os tempos, se se quer manter a boa sorte, o autor afirma: . "Já admiti, em vários pontos, que a causa da boa sorte dos homens é a conformidade da sua conduta com os tempos em que vivem (...) só quem age de acordo com seu tempo está menos sujeito a erro".

A dissertação de Maquiavel sobre o passado apresenta-se com grande riqueza de análise, de forma articulada com outras de suas teorias. Em primeiro lugar, expõe um realismo para ação, negando também qualquer intenção contemplativa ou declaração de impotência diante dos fatos, por outro lado, vai associá-lo a sua exposição sobre os conceitos de fortuna e virtù, tão debatidos em sua obra. O que isto significa? Significa que o olhar para o passado não garante, por si só, uma receita para o fazer político e, aqui, Maquiavel se refere a um saber prático, apoiado na experiência, não apresenta uma forma cientifica pelas quais os resultados serão sempre os mesmos. Ademais, num mundo político dependente dos acontecimentos humanos, há de se considerar que existe também um largo espaço para o imponderável, para as incertezas do acaso, ou conforme já havia anunciado em $O$ Príncipe: "Não ignoro a opinião antiga e muito difundida que o que acontece no mundo é decidido por Deus e pelo acaso; que a prudência dos homens não pode alterar os acontecimentos; que ao contrário não há como remediar as coisas. Talvez por isso se pense ser inútil empenhar-se nelas ". (MAQUIAVEL, 1995, p. 220).

O Autor prossegue e expõe seu pensamento para ação, a virtù é decisiva no mundo político. Ele não ignora que há uma margem de incerteza na vida, se inclina mesmo a aceitá-la. Porém, não admite que o homem seja totalmente impotente diante do acaso, do imponderável. Mesmo diante dos acontecimentos que fogem ao controle humano, ou a previsibilidade, tem que haver ação:

Compararia a fortuna a um rio impetuoso que, quando turbulento inunda a planície, derruba casas e edifícios, remove terra de um lugar para depositá-la em outro. Todos fogem diante da sua fúria, tudo cede em poder detê-la. Contudo embora tal seja sua natureza, quando as águas correm quietamente é possível construir defesas, diques e barragens, de modo que, quando voltem a crescer, sejam desviadas por um canal, para que seu ímpeto se torne menos selvagem e maléfico.(MAQUIAVEL, 1995, p. 221).

Além da beleza literária, o secretário coloca aqui um aspecto determinante para compreensão de seu realismo político e qual é a finalidade do olhar para o passado. Isto é, sobretudo, realçar a necessidade da ação do homem e convidá-lo a vencer os desafios; reconhecer que não há uma ordem preestabelecida e mesmo que o mundo esteja submetido a 
alguma contingência ou daquilo que foge a condição de sua racionalidade, não é motivo para render-se. Ao contrário, cobra dele ainda mais decisão e ação e as lições da história são decisivas. Deve-se, pois, extrair estas lições e ajustá-las ao presente. Não existe assim um quadro estático na relação do passado com o presente, há uma simbiose, também embalada pela mutação dos tempos, da fortuna, o que exige mais ainda do homem frente aos desafios da política: "acredito que é feliz quem age de acordo com as necessidades de seu tempo, e da mesma forma é infeliz quem age opondose ao que seu tempo exige".(MAQUIAVEL, 1995, p. 223).

Para Maquiavel, política esta envolvida com luta, desejo de poder, duras disputas e, aqui, a força aparece como destacado elemento. A força é a expressão máxima do realismo maquiaveliano que reconhece a necessidade do uso da violência. $\mathrm{O}$ autor defende o uso de uma "violência reparadora". Não há condenação aos meios utilizados para condução de ações políticas favoráveis ao Estado. Contudo, para o secretário florentino, nenhum poder se mantém somente com a força. Este elemento que compõe o jogo político é um recurso que pode ser utilizado quando necessário. Maquiavel vai buscar o exemplo extremo, em Roma, para demonstrar o uso da violência 'reparadora':

Muitos consideram como um mal exemplo o fato de que um fundador de um governo livre, como foi Rômulo, tenha primeiramente assassinado seu irmão, tendo concordado em seguida com a morte de Tito Tácio Sabino, com quem compartilhava o trono. Esta opinião seria bem fundamentada se não levasse em conta o motivo que conduziu aquele homicídio (...) o legislador sábio, animado do desejo exclusivo de servir não aos seus interesses pessoais, mas ao do público: de trabalhar não em favor de seus próprios herdeiros, mas para a pátria comum não poupará esforços para reter em suas mãos toda a autoridade.(MAQUIAVEL, 2011, p. 74).

O autor defende Rômulo, pelos fins que alcançou sua ação, o bem estar da pátria. Dessa forma julga que:

Nenhum espírito esclarecido reprovara quem se tenha valido de uma ação extraordinária para instituir um reino ou uma república. Alguém pode ser acusado pelas ações que cometeu, e justificado pelos resultados destas. E quando o resultado for bom, como no exemplo de Rômulo, a justificação não faltará Só devem ser reprovadas as ações cuja violência tem por objetivo destruir, em vez de reparar. (MAQUIAVEL, 2011, p. 74).

A defesa desta ação de Rômulo, que choca pela medida extrema - o homicídio do próprio irmão - alimenta a conhecida polêmica que sustenta o 
maquiavelismo ${ }^{4}$ que fez a infâmia do autor de $O$ Príncipe, ou, 'os fins justificam os meios', . Há de se considerar, por outro lado, que Maquiavel elogia também o sucessor de Rômulo, Numa, que utilizou da religião para governar e conduzir o povo, buscando evitar a violência. Maquiavel condena a violência utilizada por Agátocles, o siciliano, que ascendeu ao poder através de meios cruéis: "não se pode chamar de virtù o assassínio de seus compatriotas." (MAQUIAVEL, 1995, p. 57).

Entendemos que o autor dos Discursos não defende a política pela política; a força pela força; entender a realidade para conservá-la; ou se esta é mesmo a realidade, que assim seja e nos amoldemos a ela. O secretário florentino não se contenta em constatar os fatos, não é um realismo apenas descritivo. Para ele a realidade não é imutável. Cabe ao homem dá forma aquela matéria (realidade).

De acordo com o filósofo italiano Ernesto Grassi, o realismo de Maquiavel distingue a matéria e a forma da arte política:

\begin{abstract}
A matéria é dada pela concreta situação histórica com todas as suas possibilidades bem circunscritas. A forma é dada pela decisão do homem político que em um determinado momento histórico realiza uma possibilidade, e precisamente aquele que ele compreende fecunda para a comunidade política a qual solução ele se propõe. (GRASSI, 1949, Tomo 3).
\end{abstract}

Maquiavel não é conservador, não aceita manter o status quo, ao contrário, revoluciona o pensamento acerca da religião, da ética, dos conflitos, do papel do povo na vida política. Confrontou a condição de um personagem inoperante no palco da política ou um intelectual impotente diante da dura realidade de seu tempo. Desta forma: "o estilo de Maquiavel não é de um tratadista sistemático como os tinha a Idade Media e o Humanismo, absolutamente; é estilo de homem de ação, de quem quer impulsionar a ação".(GRAMSCI, 1978, p. 10).

Nesta perspectiva, o realismo é uma metodologia: "é uma declaração de método: a via para o conhecimento político é a observação direta e o registro, sem 'colorações' emotivas, daquilo que acontece".(PORTINARI, 2007, p. 23). Porém, um método de análise para ação. Uma ação que celebra a política em defesa de uma causa justificadora da utilização de 'meios extraordinários' para realizar 'grandes coisas'. Quais sejam: a fundação de um Estado seguro, livre e duradouro, a defesa da liberdade, da república, a defesa da pátria. É neste sentido que procura conjugar este realismo com os ideais acima referidos, ou seja, ideais republicanos, defendidos por Maquiavel, capaz de superar uma visão privada da política e dar-lhe um caráter público: "por isto uma república deve abrir caminho a

\footnotetext{
4 Maquiavelismo: astúcia, fraude, mentira, traição...

5 Esta 'sentença' não consta em nenhuma obra de Maquiavel, foi atribuída ao autor posteriormente.
} 
quem busca a popularidade pela ação pública, mas deve fechá-la aos que querem alcançá-la pela conduta privada “. (MAQUIAVEL, 2011, p. 246).

A riqueza teórica do realismo faz deste pensamento um lugar obrigatório de encontro das várias teorias sobre guerra e paz, poder, democracia, relações entre os Estados, etc., e sempre exigindo dos analistas uma especial atenção sobre um de seus elementos mais polêmicos que têm acompanhado a história da evolução das ideias políticas: o conflito. É o que passamos a tratar a seguir.

\section{Realismo político e conflitos}

Concordamos com Portinari $(2007$, p. 31) que entre os principais pressupostos do realismo, há a afirmação de que a realidade política é conflito.

O realismo de Maquiavel que chocou seus contemporâneos e ainda continua a causar impactos sobre moralistas de todas as matrizes, revela-se com maior vigor nas análises 'inovadoras' ou podemos dizer 'revolucionárias', quando na abordagem sobre os conflitos. Maquiavel analisa este fenômeno como positivo, em franca oposição às teorias políticas de seu tempo e outras precedentes, mas, sobretudo, confrontando o pensamento religioso cristão e sua moralidade, que apontava para a necessidade de construção de um mundo de concórdia entre governantes e governados capaz de moldar uma vida de paz na comunidade política. O secretário florentino nega esta possibilidade, com a afirmação de que é impossível alcançar tal fim, pela sua compreensão sobre política e pela própria natureza humana. Maquiavel constrói sua teoria política tendo como elemento primordial esta realidade conflituosa entre os homens e seus 'humores'. É nesta perspectiva que defende o modelo republicano, por considerá-lo aquele que permite a absorção das energias geradas nos conflitos para garantia da liberdade e estabilidade na comunidade política.

Este pensador florentino compreende o conflito como uma condição inerente a própria política. O conflito é fundamental para o equilíbrio das relações na vida política. Deve-se, porém, observar que o secretário quando se refere aos conflitos, afasta de suas considerações a possibilidade de conflitos pessoais produzirem fatos positivos para a vida política. Maquiavel analisa as tensões sociais, os 'humores' dos grupos que se debatem no espaço público e esta tensão é constante. Não há uma sociedade perfeita no mundo da verdade efetiva das coisas (verità effetualle delle cose). $\mathrm{O}$ equilíbrio do corpo político não é fruto da bondade de seu dirigente ou de uma vontade transcendente. A cidade se divide em duas forças, ou dois humores: os que querem oprimir ( $i$ grandi) e os que não querem ser oprimidos (il popolo). Desta tensão surge o equilíbrio do corpo político. Com esta posição Maquiavel rompe com a tradição, que interpretava os conflitos como maléficos e analisa que: 
A desunião do povo e do senado foi a causa da grandeza e da liberdade da república romana (...) digo que aqueles que criticam as disputas entre os nobres e a plebe criticam aquilo que foi a causa principal para que fosse conservado a liberdade de Roma, prestando mais atenção aos rumores e aos gritos que nasciam destes tumultos que os bons efeitos que geravam; e não levavam em conta que em toda república existem dois humores diversos, o do povo e o dos grandes. Toda lei que favorece a liberdade nasce da desunião dos elementos constitutivos das cidades como se pode ver facilmente em Roma. (MAQUIAVEL, 2011, p. 65).

\section{Segundo Marco Geuna (2005):}

O modo como é tematizado o problema da ordem e do conflito permite distinguir não apenas a teoria de Maquiavel e dos pensadores maquiavelianos das teorias republicanas de matriz aristotélica, mas também, de teorias republicanas que propõe a ideologia da concórdia ordinum de matriz ciceroniana. (...) Maquiavel elabora uma teoria política que representa uma descontinuidade radical também nos confrontos das teorias republicanas pré-humanistas e humanistas que contra os perigos constituídos pela emergência das facções, propõe as lições de De Officiis que insistia com vigor sobre a importância da concórdia na vida civil . (GEUNA, 2005, p. 41-43).

Maquiavel entende que é vã a tentativa de extirpar os conflitos na sociedade, primeiro, porque é da natureza humana, conforme aqueles humores, segundo, porque seria negar a dialética que tem mesmo movido a marcha política para adiante. O conflito por si só não é bom. Significa dizer, que não se deve ver como bom o conflito pelo conflito, aliás, pode levar a anarquia, a desordem. A questão é saber reconhecer as suas causas e administrá-lo com eficácia, tirando dele um resultado positivo para o equilíbrio do corpo político e o fortalecimento do Estado. Como afirma Bignotto: "O importante não é suprimir os conflitos, mas sim evitar que eles destruam a possibilidade de convivência entre os membros de uma mesma comunidade política".(BIGNOTO, 2003, p. 50)

Quentin Skinner registra que Maquiavel inova o pensamento humanista que já havia afirmado a necessidade de participação dos cidadãos nos negócios públicos, e a liberdade seria conservada pela virtù dos cidadãos. Ocorre, porém, prossegue Skinner, ter escapado desta abordagem, que os 'tumultos' são justamente o resultado da participação política, revelando-se assim em uma alta virtù. Os humanistas não compreenderam Maquiavel quando defende que "toda a legislação que favoreça a liberdade decorre do choque entre as classes e, por isso, o conflito de classes não é o solvente, mas o cimento de uma república".(SKINNER, 1996, p. 202). Esta abordagem inovadora é chocante diante de uma tradição que via nos 
conflitos a ameaça da liberdade. Para o historiador florentino e amigo de Maquiavel, Francesco Guicciardini, "louvar a desunião é como elogiar a doença de um enfermo, devido à virtude do remédio aplicado para curá-lo". (SKINNER, 1996, p. 202)

$\mathrm{Na}$ interpretação dos conflitos, encontra-se também de forma contundente, a negativa contra o pensamento utópico, realçando o realismo do secretário. A negação do conflito é um pensamento utópico que imagina haver um 'congelamento' das relações sociais num mundo estático.

Em $O$ Príncipe, quanto nos Discursos, o autor afirma que o povo não deseja ser oprimido, enquanto os poderosos desejam oprimir, e destes dois desejos opostos podem surgir um governo absoluto, a liberdade ou a desordem: "de fato, o povo tem objetivos mais honestos do que a nobreza; esta quer oprimir, enquanto o povo deseja apenas evitar a opressão".(MAQUIAVEL, 1995, p. 63). Maquiavel analisa que do choque entre estas forças contrárias nasce a liberdade, como foi em Roma, ou também pode gerar a desordem ou um governo opressor. Mas, como então explicar que um mesmo fenômeno pode produzir efeitos distintos, como se verificou em diferentes cidades?

Na História de Florença, no Livro III, o autor elabora uma solução para o problema. De início reconhecendo que as "inimizades que existem entre as pessoas do povo e dos nobres, causadas por que estes últimos, querem mandar e aqueles não querem ser mandados" - aqui o autor reafirma a teoria dos conflitos que apresenta em O Príncipe e nos Discursos, - estas 'inimizades' são os motivos dos males que nascem nas cidades, prossegue o autor, justificando que os conflitos podem produzir efeitos bem diferentes, assim aconteceu em Roma e em Florença:

Diversos foram os efeitos resultantes numa e noutra cidade, convenha-se porque as inimizades que no início surgiram em Roma entre o povo e os nobres definiram-se discutindo, e em Florença combatendo; as de Roma com a Lei e as de Florença com a morte e com o exílio de muitos cidadãos terminaram; as de Roma sempre as virtudes militar aumentaram, as de Florença de todo apagaram-na; as de Roma de uma igualdade entre os cidadãos, a uma grandíssima desigualdade conduziram as de Florença. (MAQUIAVEL, 2011, p. 529).

O efeito negativo para o jogo político que emergiu dos conflitos entre as forças florentinas foi fruto da má administração daquelas 'inimizades'. Duas forças em choque que acabaram tendo como resultado a vitória de uma sobre a outra. Ainda no Livro III - História de Florença: "Esta diversidade é natural que provenha dos diversos fins a que se propuseram estes povos". Em Roma, o povo tinha como objetivo a repartição do poder junto aos nobres, ao contrário de Florença onde apenas uma parte (popoli) negava participação dos nobres no governo. Em Roma, quanto mais razoável era o desejo do povo, mais os nobres suportavam suas 
ofensas. A nobreza pela 'pressão' acabava cedendo, e sobre o efeito desta tensão era razoável que a solução fosse a criação de uma lei que atendesse os reclamos do povo e ao mesmo tempo não retirando a dignidade dos nobres. O povo via-se assim contemplado em seus desejos e a participação no poder junto aos nobres deu-lhe uma vitoria que fez a cidade ainda mais virtuosa, mais potente.

Por um caminho diferente de Roma, em Florença os conflitos resultaram não em uma 'negociação' entre as forças opostas que comportasse no poder as duas partes, ao contrário, viu-se a imposição de um desejo sobre o outro, uma solução unilateral, assim a intransigência do povo levou a nobreza a preparar-se com maior força. Não houve uma saída que preservasse ambos 'humores'. Uma parte vencendo, subjugando a outra, criava leis que não beneficiavam a todos, mas só o lado vencedor. Vê-se que os elogios de Maquiavel aos conflitos se justificam quando estes conduzem a um equilíbrio das forças políticas, somente assim é possível oferecer estabilidade ao governo, criar leis favoráveis a liberdade. A este propósito Newton Bignotto esclarece que:

Das duas forças principais que dividem a cidade, não podemos dizer que elas sejam o inverso simétrico uma da outra. $\mathrm{O}$ povo, não visando à mesma coisa que os grandes, não pode ser compreendido pela imagem do inimigo organizado num campo de batalha. Daí resulta que a liberdade não é um meio termo estático que satisfaz os desejos dos dois oponentes. Tal fim é absolutamente impossível de ser alcançado por dois adversários que não tem o mesmo objetivo. A liberdade, mais do que uma solução permanente para as lutas internas de uma cidade, é o signo de sua capacidade de acolher forças que, não podendo ser satisfeitas, não deixam de buscar meios de se exprimir. (BIGNOTTO, 1991, p. 86).

O conceito de estabilidade também se apresenta novo. Não é compreendido como ausência de movimento. O realismo de Maquiavel ganha outra dimensão, incorporando outros elementos, conforme reconhece Marco Geuna:

\footnotetext{
Não temos somente o elogio da desunião frente ao elogio da concórdia, mas uma mudança de todo significado de estabilidade. Se na perspectiva tradicional o governo misto vinha apresentando uma perspectiva estática, Maquiavel o tematiza, ao contrário, em uma perspectiva toda dinâmica. Em um contexto como aquele interestatal em perene tensão e mudanças. Estabilidade não significa estática perfeição, mas capacidade de movimento. Se conservar estável, permanente, não é imóvel, mas relacionando-se continuamente ao contexto, que se move na mesma velocidade, que se encontra com o tempo.
} 
Continua Geuna, agora relacionando os conflitos com os acontecimentos do exterior da república, com a história, o tempo e definitivamente negando qualquer utopia.

\begin{abstract}
Uma continua tensão interna na república, portanto, relacionando-se as tensões que existem em seu exterior. Uma continua tensão entre popoli e grandi, e entre os organismos constitucionais diversos, para fazer frente as tensões que continuamente existem entre aqueles corpos que procuram sua segurança, tentando aumentar seu poder. As estruturas constitucionais, portanto, não vão considerar as abstratas e estáticas perfeições, mas pela sua capacidade de relacionar-se aos conflitos do tempo, a qualidade dos tempos. Com esta proposta radicalmente dinâmica, Maquiavel não somente põe em estreita relação política interna e externa, mas junta de modo inseparável, política e história. (GEUNA, 2005, p. 30).
\end{abstract}

A história é dinâmica, o conflito apresenta complexidade singular em cada cidade e Maquiavel faz uma observação a este respeito. Não há uma solução única para cada conflito que se apresenta em diferentes circunstâncias. Para melhor compreensão do caso romano, faz-se necessário uma leitura do Primeiro Livro dos Discursos, Capítulo segundo, conjugando-o com o terceiro e quarto.

Maquiavel trata dos conflitos e seus efeitos analisando-os também frente aos ordenamentos das cidades: "Feliz é a república à qual o destino outorga um legislador prudente cujas leis se combinam de modo a assegurar a tranquilidade de todos" (MAQUIAVEL, 2011, 61). Prossegue Maquiavel, "É o que se viu em Esparta, onde as leis foram respeitadas durante oito séculos sem alterações e sem desordens perigosas". (MAQUIAVEL, 2011, 61). Observe-se, porém, que quando Licurgo elaborou aquela constituição de Esparta fez com que houvesse um equilíbrio entre o poder do rei, da aristocracia e do povo. Roma não teve a fortuna de Esparta. Seu ordenamento foi construído através dos tempos, nas disputas. Na república havia representação de duas forças: a monarquia e a aristocracia, (cônsules e senado). O povo estava excluído. Diz Maquiavel que "a nobreza tornou-se insolente o que despertou o ressentimento do povo, para não perder tudo, teve que ceder-lhe parte da autoridade (...). Estas foram as causas que originaram os tribunos do povo" (MAQUIAVEL, 2011, p. 64). Formandose um governo misto, fruto dos conflitos entre o povo e a aristocracia "o equilíbrio dos três poderes fez assim nascer uma república perfeita e a fonte desta perfeição foi a desunião do povo e do senado". (MAQUIAVEL, 2011, p. 64).

O mesmo sucesso de Esparta, não obteve Atenas, com Sólon, que legislou apenas para servir ao governo popular, faltou contemplar os interesses do príncipe e dos aristocratas, o que acabou por abrir caminho para a tirania de Pisístrato. E mesmo com o fim da tirania e as reformas na 
constituição, porém sem a participação equilibrada das forças do príncipe, da aristocracia e do povo, o seu sucesso foi efêmero.

Mas, como responder sobre Veneza, que sem conflitos garantiu tempos de liberdade? Isto exige de Maquiavel uma abordagem a partir de outro ângulo. $\mathrm{O}$ autor tem consciência das controvérsias que suas formulações suscitarão, desta forma, para não permitir ambiguidades em suas leituras, não pretende deixar o leitor na superfície, convida-os então a profundidade do problema: "para fazer um julgamento seguro, é preciso passar os olhos sobre as repúblicas que, sem discórdias e inimizades, gozaram longamente de liberdade" (MAQUIAVEL, 2011, p. 68). Maquiavel admite que existam outros fatores fundantes da liberdade, resta saber se isto, sendo factível, poderia ser introduzido em Roma. Utiliza então os exemplos de Esparta e Veneza, duas repúblicas onde não se verificaram as relações conflituosas de Roma e mesmo assim garantiram por longo tempo suas liberdades. A resposta do autor, longe de embaraçá-lo, clarifica a questão.

No Livro I, Capítulo 06 dos Discursos, desvendando a questão de Veneza, em primeiro lugar, naquela cidade não houve a divisão de poder em diferentes denominações. Todos que participavam tinham a mesma denominação 'gentiluomini'. Isto se deveu mais à fortuna do que à virtù. Todos os habitantes participavam do poder, o que evitou a luta de parte da população que estivesse excluída. O governo instituído inibiu ou não justificou o desejo de promover tumultos. Não havendo desequilíbrio do corpo político "os que vieram depois não eram suficientes para romper este equilíbrio entre governantes e governados". (MAQUIAVEL, p. 68), isto aliado a um governo de pulso firme, possibilitou a unidade da república.

Por sua vez, Esparta foi "governada por um reino e sendo pouco numeroso com o olhar mais voltado para dentro do que externamente a população submeteu-se completamente as leis de Licurgo". (MAQUIAVEL, 2011, 68) - como, aliás, já nos referimos em páginas anteriores - "onde se verificava mais igualdade de substância do que de grau".(MAQUIAVEL, 2011, p. 68). Não havia em Esparta um abismo separando as 'classes', havia uma igualdade na população, mesmo que fosse na pobreza e aqueles a quem o Estado beneficiava era em pequena quantidade e a "conduta destes não era de molde a despertar a inveja dos populares". (MAQUIAVEL, 2011, p. I68).

Ademais, os reis de Esparta não trabalhavam para os grandes e mantinham sempre a defesa do povo, evitando-lhes qualquer insulto. Por isto o povo "nem temia nem almejava o poder, pelo que desapareceram os germes dos tumultos e todos os pretextos de discórdia entre ele e a nobreza" (MAQUIAVEL, 2011, p. 68).

Portanto, elementos como a pequena população, a recusa em receber estrangeiros, a razoável igualdade da população, a submissão à lei, entre outros, permitiram uma razoável unidade e paz nestas repúblicas. Todavia, 
Maquiavel demonstra mais um argumento que diferencia estas repúblicas de Roma. Não bastam estes elementos internos para manter uma república por muito tempo sem conflitos. Aqui o autor introduz um fator que, além de reforçar seus argumentos, coloca em campos bem diferentes aquelas repúblicas, isto é, há de se verificar as circunstâncias externas, suas perspectivas de poder e a visão sobre o jogo político no cenário internacional.

A resposta de Maquiavel não poderia ser mais clara. Diferentemente de Veneza e dos Lacedemônios, Roma nem negou cidadania aos estrangeiros, nem desobrigou seus cidadãos do serviço militar, fez as duas coisas "o que aumentou o número e a força do povo, multiplicando em consequência as fontes de distúrbios”. (MAQUIAVEL, 2011, p. 68 ). Daí Maquiavel relacionar a grandeza de Roma aos conflitos.

Se a república de Roma tivesse sido mais pacífica, o resultado teria sido inconveniente, sua debilidade teria aumentado e ela talvez ficasse impossibilitada de trilhar os caminhos da grandeza que mais tarde seguiu de modo que se os romanos tivessem querido preservar-se dos tumultos, deixariam de ter todos os meios para desenvolver-se . (MAQUIAVEL, 2011, p. 69).

Isto significa que os conflitos em Roma foram responsáveis não apenas pela liberdade, mas pela sua expansão e força militar. $\mathrm{Na}$ análise comparada entre estas repúblicas, a posição de Maquiavel é clara: prefere Roma, que, em busca de aumentar sua potencia e se ampliar, como forma inclusive de garantir sua sobrevivência e segurança, incorporou seu povo nos mecanismos de poder.

Procuremos esclarecer: Se dos conflitos, no caso de Roma, onde o povo assumiu significativa participação nas decisões, com o equilíbrio das partes satisfeitas, estão eliminados os conflitos? A resposta é não.

Segundo explica Jose Luiz Ames:

O desacordo não tem como ser resolvido nem eliminado, porque cada um dos dois desejos tem um modo de desejar diferente. Desta maneira o conflito não consiste na disputa em torno de um mesmo objetivo. Se fosse poderia ser resolvido pela imposição de uma das partes sobre a outra (...). Seria um absurdo, para Maquiavel, pretender que, com a destruição dos grandes ou com a emancipação plena do povo, estaria solucionado, de forma definitiva, o conflito social. (AMES, 2008, p. 55-56).

Parecem suficientes as respostas oferecidas por Maquiavel aos questionamentos sobre os conflitos, mas nem tudo está resolvido. Há uma dificuldade a superar. O conflito criado em Roma pela lei agrária em vez de garantir a liberdade, pelo contrário, fez um grande mal e "a cidade nunca 
mais voltou a ser livre". A este propósito o autor adverte: "e se o que digo aqui sobre os seus efeitos (dos conflitos) parece contradizer o que demonstrei alhures (que a inimizade do povo e do senado de Roma contribuiu para manter sua liberdade) direi que não é assim" (MAQUIAVEL, 2011, p. 111). Vamos procurar resolver esta questão a partir do que propõe o chanceler de Florença.

Para Maquiavel, a natureza criou o homem com o desejo de tudo querer possuir, sem que tenha capacidade de atender este desejo. A vontade é bem superior a real capacidade de satisfazê-la, e disto decorre uma grande frustração. Forma-se o conflito porque uns querem ter, outros temem perder o que tem. O povo lutou para repartição do poder em Roma, vitorioso, formado o tribunato da plebe, quis ir mais além. Não bastava o poder político, queria da nobreza suas riquezas e honrarias, "os dois bens mais cobiçados". Os tumultos se disseminaram e como "uma epidemia invadiram a cidade por ocasião da lei agrária e, que, finalmente, levaram a república à ruína". (MAQUIAVEL, 2011, p. 111).

A lei agrária colocava limites à propriedade de terras e determinava que as novas terras conquistadas fossem repartidas entre todo o povo. Ora, qual a consequência desta lei? Em primeiro lugar, punia os nobres que limitados a certa quantidade de terra perderia o excedente que possuía e, mais ainda, as novas terras conquistadas sendo distribuídas entre o povo, impedia o aumento de suas riquezas (nobres). A situação provocada pela lei agrária em Roma foi responsável por distúrbios que causaram prejuízos enormes a república.

Após marchas e contramarchas "estourou a guerra civil; o sangue correu em torrentes e depois de muitas vicissitudes a nobreza alcançou a vitória".(MAQUIAVEL, 2011, p. 111). De maneira, que destes 'tumultos' emergiu a figura de Cesar "que foi o primeiro tirano de Roma. Cidade que nunca mais voltou a ser livre".(MAQUIAVEL, 2011, p. 111). É interessante perceber que até aqui, dos conflitos surgem leis que garantem a liberdade. Porém, no caso em tela, em processo inverso, foi uma lei que produziu conflitos acabando com a liberdade.

Para Maquiavel, este episódio que comprometeu a liberdade romana, demonstra que os homens:

Se interessam mais pela riqueza do que pelas honrarias. Com efeito, a nobreza romana cedeu à plebe, sem excessiva relutância, uma parte de suas honrarias; mas quando se tratou de ceder-lhe riquezas, defendeu-as com tal determinação que o povo, para satisfazer sua fome de ouro, teve de recorrer a meios privados. (MAQUIAVEL, 2011 p. 111).

Maquiavel conclui que a ambição dos poderosos é desmedida (não tem fim) se "o Estado não procurar esmagá-la sem piedade de todos os meios e modos, ela o arrastará a sua queda”. (MAQUIAVEL, 2011, p. 111). 
A lei não foi capaz de conter a ambição dos grandes. A corrupção demonstrou seu poder corrosivo e começou a destruir a república. Quando as origens foram econômicas (aumento da riqueza privada), as energias do conflito foram direcionadas para interesses que não eram públicos. $\mathrm{O}$ conflito sobre a lei agrária estava revestido de um caráter privado de interesse econômico. Não se tratava mais de uma contenda por espaços nos mecanismos de poder ou por liberdade. A luta pelo aumento de riquezas privadas corrompeu os homens e feriu de morte os valores republicanos.

Maquiavel já havia defendido que "num governo bem organizado o Estado deve ser rico, e os cidadãos, pobres" (MAQUIAVEL, 2011, p. 110). $\mathrm{O}$ Estado rigorosamente não pode permitir que os homens tenham condições de corromper ou ser corrompidos. A luta insaciável pela riqueza privada ameaça o Estado. Quando a corrupção contamina o corpo político a primeira vitima é a liberdade e daí decorre que "onde a matéria está tão corrompida, não bastam leis para contê-la, é preciso ordenar junto com elas uma maior força que é uma mão régia com poder absoluto e excessivo que ponha freio a excessiva corrupção e ambição dos poderosos diante da corrupção". (MAQUIAVEL, 2011, p. , 37). Aqui se abre uma nova etapa na vida das repúblicas, no ciclo inevitável da história, serão suspensas as liberdades, para reconstruir o Estado, num momento de exceção, e daí novos conflitos, nova reorganização das forças políticas, novas leis e o surgimento de um novo tempo de liberdade.

\section{considerações finais}

Há uma intrínseca relação entre conflito e realismo político. Vê-se que é vã a busca para evitar os conflitos, assim como não é possível afastar tantas vezes a utilização da força para reprimir os desejos particulares. Nesta perspectiva, a ação em face dos conflitos deve se direcionar sempre no sentido de preservar os interesses coletivos, ação que carrega, em seu conteúdo, um compromisso com os valores republicanos. O Estado desta forma, tem a necessidade de auto preservação para poder manter seus objetivos, o que não pode prescindir da utilização da força quando necessário na intervenção sobre os conflitos formados por interesses particulares, de 'facções'. A análise maquiaveliana sobre os conflitos, além de inovadora, revela que há também naquele pensamento a expressão de uma ética política uma vez que os conflitos devem ser administrados em defesa da liberdade, para garantia da república. 
Daquela tradição interpretativa sobre o pensamento do florentino que o identifica como preceptor de tiranos ou arquiteto de regimes totalitários, escapou justamente esta análise sobre os conflitos. Vejamos pelo registro de Jean-Jacques Chevalier: "Julgou-se que a derrota de Hitler era a derrota de Maquiavel, mas a derrota de Hitler é em grande parte, a vitória de Stálin”. (CHEVALIER, 1998, p. 48). Tal conclusão não se permite a partir do tratamento que o secretário confere aos conflitos, uma vez que estes equilibram o corpo político, o que é totalmente dissonante com um regime autoritário. Maquiavel propõe que as tensões das lutas políticas, dos 'humores' da cidade, encontrem seu lugar num poder político bem ordenado. Não há exclusão de nenhuma parte em conflito, aliás, ao contrário, a exclusão de forças participantes do cenário político levou a ruína da república romana e as grandes crises em Florença. Regimes autoritários não convivem com conflitos, logo, esta análise nos permite concluir que o autor dos Discursos não pode ter seu pensamento utilizado para justificativa de regimes autoritários que são completamente intolerantes com qualquer discórdia e historicamente tem demonstrado que usam a força, sem limites, quando necessário para sufocar as 'oposições' aos seus mandos. O tratamento aos conflitos proposto pelo secretário florentino se coaduna com um ambiente democrático. O modelo republicano de Maquiavel não exclui nenhum segmento social. A república pensada por Maquiavel tem a marca da tolerância com as forças contrárias.

\section{Referências bibliográficas}

AMES, Jose Luis. Uma teoria do conflito em Maquiavel e Marx. IN: 
Revista Educare. Vol. 3, no. 6, jul-dez., 2008.

ANAROVICH, Patricia Fontoura. História e Política em Maquiavel. São Paulo: Discurso Editorial, 2007.

BIGNOTTO, Newton. Maquiavel. Rio de Janeiro: Jorge Zahar Ed., 2003. BIGNOTTO, Newton. Maquiavel Republicano. São Paulo: Loyola, 1991. CHEVALIER, Jean-Jacques. As grandes obras políticas de Maquiavel a nossos dias,. Trad., Lydia Cristina. 8ª Ed., Rio de Janeiro: Agir, 1998.

ESCOREL, Lauro. Maquiavel: Um seminário na Universidade de Brasília. Brasília: Editora UnB, 1981.

GEUNA. Marco. Machiavelli ed il Ruolo dei conflitti nella vita politica. IN: Conflitti. A cura di Alessandro Carienze e Dario Caruzo. Napoli-Itália: Edizioni Libreria Dante \& Descartes, 2005.

GRAMSCI, Antonio. Maquiavel, a política e o Estado Moderno. Trad., Luiz Mário Gazzeano. $3^{\text {a }}$., Ed., Rio de Janeiro: Civilização Brasileira, 1978.

GRASSI, Ernesto. Actas del Primer Congresso Nacional de Filosofia. Mendoza. Argentina. Marzo-abril , 1949 - Tomo 3.

HOBBES, Thomas. Leviatã: ou matéria, forma e poder de um estado eclesiástico e civil. Trad., Alex Martins. São Paulo: Martin Claret, 2004.

MACHIAVELLI, Nicolò: Tutte le Opere, storiche, politiche e letterarie. A Cura di Alessandro Capata. Edizioni Integrali. Roma; Newton \& Compton editori, 2011.

PLATONE. Tutti gli scritti. A cura di Giovanni Reale. Milano: Rusconi, 1996.

PORTINARO, Pier Paolo. El Realismo Político.1.Ed., Buenos Aires: Nueva Vision, 2007.

SKINNER, Quentin. As Fundações do Pensamento Político Moderno. Trad., Renato Janine Ribeiro e Laura Teixeira Motta. São Paulo: Companhia das Letras, 1996.

TUCIDIDES. História da Guerra do Peloponeso. Trad., Mario da Gama Kury. Brasília: Editora Universidade de Brasília, 1987.

VERGNIÈRES, Solange. Ética e Política em Aristóteles : physis, ethos, nomos. Trad. Constança Marcondes Cesar. São Paulo: Paulus, 1998. 